\title{
FITNESS MARKET IN POLAND AND ITS DETERMINANTS
}

\section{KRZYSZTOF CIEŚLIKOWSKI, ${ }^{1}$ JOANNA KANTYKA ${ }^{2}$}

\author{
University of Physical Education in Katowice, POLAND \\ ${ }_{1}$ e-mail: k.cieslikowski@awf.katowice.pl \\ 2 e-mail: j.kantyka@awf.katowice.pl
}

RECEIVED
ACCEPTED
JEL
CLASSIFICATION

KEYWORDS

ABSTRACT
13 July 2017

15 December 2017

Z20, L83, M38, R11

sport management, fitness market, marketing

The aim of the article is to identify the key factors of the development of the fitness services market in Poland, taking into account the social and economic functions of the entities operating on this market. Authors were used the methods of observation and analysis, with dates and statistics from secondary sources from the world and Poland, as well as the results of the authors' own research published in other reports.

The paper is listing a broad spectrum of factors influencing the development of the fitness services market, assigned to 4 groups: political and legal, economic, social, technical and technological (PEST). In summary, Authors ware pointed out that the results are related with general megatrends of the world economy as well as the specifics of the development of the Polish economy and other areas of social life for last few years.

Research and inference focuses on the analysis of the overall sport activity Polish residents, the popularity of sports, the role of selected fitness clubs and operators in the development of this market. Managers of many companies operating on the market can use described in the paper examples of fitness operators in Poland. This article is a kind of review and at the same time a presentation of a concept of development of fitness services in the contemporary Polish economy.

\section{Introduction}

The fitness market in Poland has grown dynamically in both supply and demand side for the last few years. It is necessary to define the concept of the fitness market in terms of subject and subject, and to present the role of individual entities operating on this market. 
Analysis of reports of public and private institutions, both domestic and abroad, shows the dynamics and causes of the development of this market. Poland is ranked as one of the 10 most attractive countries for fitness market development in Europe. The authors point to a broad spectrum of factors influencing the development of the fitness services market. They analyze the external sources and develop their own research of these factors using the PEST technique. Authors identify factors that promote growth or limit development of fitness services in Poland.

The study and conclusions focus on analyzing the various forms of sport activity of the Polish population, the popularity of sports, the involvement of enterprises in the development of the fitness market. Authors are aware of the limitations associated with these studies and the conclusions and by analyzing only a part of the market. There are access was hampered by only few reports of the market in Poland.

There is still lack of statistic of the market, the reports are irregular, and there are different methodology of research and terminology. Forecasting limitations is also a result from the high dynamics of changes in the companies on the market and/or the development of services (offers) in fitness clubs. The topic related with fitness services seems particularly interesting, because the market has not yet been thoroughly explored, especially in terms of the many different functions of this form of recreation and sport activity and the economic effectiveness of private and public operators on the market.

This article is of a review, contains actual data on the development of this market in Poland as well as a wide overview of perspectives on the customer service process on institutional and individual fitness market. The article concludes with a summary of the concept of fitness services development in the contemporary Polish economy.

\section{Fitness services market - subject and object approach}

The market in terms of economics is defined as the general relationship between sellers and buyers. The sellers (they represent supply side of the market) have to offer exchange items (products, services, jobs, etc.) and the buyers (they are demand side of the market) are interesting in purchase of the products. Operators representing supply and demand, they participate in the process of shaping these categories and their correlations (Wrzosek, 2002).

There are various criteria for market segmentation in the literature (Wrzosek, 2002): the criterion of exchange items (product market, service market, labor market, money market), criterion of market actors (referring to the type of entities and their number on the supply and demand side), spatial criterion (spatial extent of promotional campaign).

To understand the market in subject, there are no products but on the market are the main functions of the products, expressed in the ability to meet specific needs. The market by object is the type of consumers and buyers demanding a variety of products (Niestrój, 1996).

The fitness market can be distinguished by accepting the criterion of market segmentation, the needs of those interested in maintaining or improving their physical condition, appearance or well-being, the need for physical activity using specialized equipment outside their place of residence.

In terms of marketing, buyers on the market are the ones submitting such needs (Kotler, 1994), and in economic terms of market there are suppliers and consumers of various products being traded to meet any of the needs described. The subject of the fitness market deals with services aimed at offering human psychological and sociological well-being, combined with the pursuit of optimal physical fitness (Panfil, 2016). 
Considering the nature of the clients and the manner of his conduct, in the economy can also be distinguished (Fonfara, 2015): consumer market and institutional market (B2B - "business to business" or enterprise market).

There is growing interest of institutional clients (both non-profit organizations, public administrations, and profit-oriented enterprises) in the fitness services market in the purchase for their employs of various service packages (Raport, 2015) offered by fitness clubs. Fitness club is specialized facility, where fitness services are provided.

Individual clients in the fitness services market are a specific and highly diverse social group. Their preferences change and develop under the influence of many factors. Predicting these changes, identifying the main determinants influencing the behavior of the buyers and their preferences, seems to be one of the key success factors for companies operating in this market.

The characteristics of the community, the society in which the individual client lives, are coming from individual characteristics, so, the society consist of the individuals from which it was formed (Gardawski et al., 2008) and can be described in economy by many features. Then it will be a market - a specific market, e.g. fitness services market.

Given the market in economics, there is also a supply side. The supply side includes a group of market entities that provide tangible and intangible products to meet customer needs. On the supply side of the fitness market, there are gyms with fitness services, swimming pools with extracurricular activities, other sports facilities, as well as hotels with sports facilities, multifunctional large facilities with exercise rooms and activities as well as fitness clubs. On the supply side of this market are also suppliers for which the fitness market is an added market. ${ }^{1}$ There are also instructors, trainers, or media professionals promoting fitness on the supply side of fitness market.

It is interesting to note that the market for fitness also included entities coordinating the development of this market, the so-called coordinators who use direct contacts with corporations, legal and tax expertise, to become advisors to institutional clients in fitness services for their employees.

In Poland, coordinators offer cards with access to a wide range of fitness services - the so-called: sports and leisure loyalty cards, usually dedicated to employees. ${ }^{2}$ These cards allow access to physical activity classes (including swimming pools, gyms, fitness centers, etc.) in all cooperating institutions, with no time limits and declarations for the use of sports facilities in Poland. It is estimated that loyalty cardholders are about $50 \%$ of people exercising in fitness facilities in Poland (Pestka, 2015).

\section{Developing the fitness services market in Europe and in Poland}

Sport is a diverse and multifaceted field of human life. ${ }^{3}$ Research and statistical institutions are attempting to measure this phenomenon for the purpose of monitoring its state and collecting data that are necessary for decision-making process in the sports services market. And the fitness market is part of the sports market and is related to the same processes.

Contemporary sport can be treated as a lifestyle, aiming to improve physical and mental health but sport is also an economic phenomenon that is subject to professionalization and commercialization (Sznajder, 2015).

\footnotetext{
${ }^{1} \mathrm{Eg}$, food manufacturers supporting the physical activity of individuals exercising, manufacturers of equipment of the fitness clubs, clothing producers, or ICT providers).

2 The most popular are: Multisport, OK System, Be Active, Fit Profit.

${ }^{3}$ Persons using fitness services are participating in sports activities by this way. They are able to ad hoc or in an organized way influence physical fitness or mental health, develop social relationships or achieve sports performance at different levels.
} 
Fitness services on this market are also subject to this process. There is a process of improving the management of fitness clubs on the market. Fitness clubs offer have wider range of services year by year. The clubs organize group and individual activities with professionals in the field, offer extensive methods of physical activity funding, or forms of contact with the client (including online services).

The fitness market in Europe is developing (European..., 2017) towards the growth of low-cost clubs with limited customer support. ${ }^{4} \mathrm{It}$ is also expected to further consolidate the market and its further development of fitness clubs chain groups.

Healthy lifestyle is becoming more and more popular in the modern world, and consequently the popularity of various sports activities is growing. The study of sport activity in Poland in 2013 (Raport z badań, 2013) showed that two thirds of the respondents (66\%) had sports or exercise during the year, $40 \%$ taking physical activity regularly and $26 \%$ sporadically. Sporting is primarily the domain of young, well-educated people, satisfied with their financial situation, urban dwellers (Raport, 2015). The inhabitants of Poland most often practice sports for health (70\%) and for pleasure (61\%). Nearly every second physical activity participant declares that he exercises for a better mood to relieve stress, be in good shape (47\%).

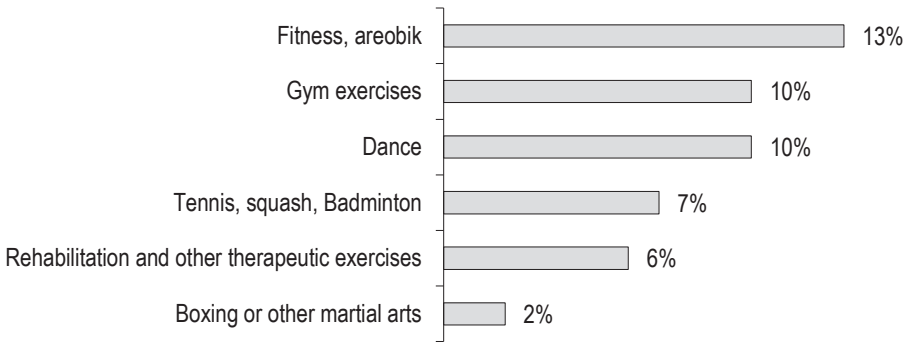

Figure 1. Sport activity of the inhabitants of Poland for selected occupations in indoors venues

Source: own elaboration based on report (Raport z badań, 2013).

There are the most popular are fitness and aerobic venues (13\% of respondents) in Poland, considering the sites of sports activity in Figure 1. According to this, there is the number of facilities, where in modern air-conditioned rooms, on brand new equipment, under the supervision of qualified instructors who want to improve or maintain physical fitness can do it. The development of material infrastructure is accompanied by the development of new forms of financing using motivational systems, where benefits - such as gym cards - are the second most popular non-salary motive offered to employees.

In Europe more than 56.4 million people attend to fitness clubs. This number is bigger about $4.4 \%$ than a year ago (The European Health \& Fitness Market, 2017). The European fitness market is worth over $€ 26.3$ billion (Table 1). The Polish fitness market is one of the top 10 markets in Europe and one of the most dynamically

\footnotetext{
${ }^{4}$ E.g. Mrs. Sporty in Poland.
} 
developing. In December 2016 in 2,560 fitness clubs in Poland already had 2.835 million clubbers (Table 2), which gives about 1,710 people per fitness club (5 times less than in Germany or Great Britain).

Table 1. European fitness clubs market in 2016

\begin{tabular}{clccc}
\hline No. & \multicolumn{1}{c}{ Country } & $\begin{array}{c}\text { Revenues } \\
(\mathrm{mln} \text { Euros })\end{array}$ & $\begin{array}{c}\text { Share in the European market } \\
(\%)\end{array}$ & $\begin{array}{c}\text { Share cumulatively } \\
(\%)\end{array}$ \\
\hline 1. & Great Britain & 5,108 & 19.39 & 19.39 \\
2. & Germany & 5,050 & 19.17 & 38.56 \\
3. & France & 2,465 & 9.36 & 47.92 \\
4. $\quad$ Italy & 2,215 & 8.41 & 56.33 \\
5. Spain & 2,171 & 8.24 & 64.57 \\
6. & Holland & 1,324 & 5.03 & 69.59 \\
7. & Russia & 1,180 & 4.48 & 74.07 \\
8. & Turkey & 1,015 & 3.85 & 77.93 \\
9. & Poland & 842 & 3.20 & 81.12 \\
10. Switzerland & 842 & 3.20 & 84.32 \\
11. & Others & 4,131 & 15.68 & 100.00 \\
\hline European market total & 26,343 & 100.00 & \\
\hline
\end{tabular}

Source: study on report European Health \& Fitness Market Report (2017).

Experts say, that total numbers of members of fitness clubs in Poland can increase to 4 million in a few years, including a large proportion of older people. By analyzing the index of penetration (the ratio of the number of members of fitness clubs to the population of the country) among the top ten fitness markets in Europe, the highest (over 16\%) indicator is in the Netherlands (Table 2).

Table 2. Countries with the highest number of members in fitness clubs in Europe in 2016

\begin{tabular}{|c|c|c|c|}
\hline No. & Country & $\begin{array}{l}\text { Numbers of fitness club members } \\
\text { (million) }\end{array}$ & $\begin{array}{c}\text { Penetration index ratio } \\
(\%)\end{array}$ \\
\hline 1. & Germany & 10.080 & 12.30 \\
\hline 2. & Great Britain & 9.250 & 14.10 \\
\hline 3. & France & 5.460 & 8.20 \\
\hline 4. & Italy & 5.250 & 8.70 \\
\hline 5. & Spain & 5.060 & 10.90 \\
\hline 6. & Russia & 2.920 & 2.00 \\
\hline 7. & Holland & 2.840 & 16.70 \\
\hline 8. & Poland & 2.835 & 7.40 \\
\hline 9. & Sweden & 2.080 & 21.10 \\
\hline 10. & Turkey & 1.900 & 2.40 \\
\hline
\end{tabular}

Source: based on European Health \& Fitness Market Report (2017).

In Poland, the penetration rate is $7.4 \%$, which is below the average for all analyzed countries, which is $8.1 \%$. The Delloite Report, uses a wide range of definition of a fitness club. The fitness club is a venue open to all people, with facilities dedicated to sport, which has equipment for endurance training, fitness and physical fitness. For the 
total number of fitness clubs, the report also includes swimming pools and dance schools only if they have fitness rooms. In Poland in 2016 there were 2,560 fitness clubs and a year before it had 2,520. So the market is growing. Older venues are closed (European Health \& Fitness Market Report, 2017).

Some authors point out that the fitness market has become a highly profitable market for innovation, especially micro and small businesses in the area of process and product innovation (Kantyka, Maciag, 2013). However, it should be remembered that in Poland also develop network fitness clubs. ${ }^{5}$ As it was mentioned earlier, in December 2016 in Poland there were a total of 2,560 fitness clubs, with 216 of them being network clubs, i.e. 8.4\%. Despite the small share of network clubs, watching the other services market (e.g. hotelier) it seems that these networked clubs may be the source of further professionalization of services and impose certain standards in this market. ${ }^{6}$ Clients in modern fitness clubs can use a wide range of services. They can engage in the process of creating offers at the emotional, physical, intellectual and even emotional levels. It is related with the development of experience economy (Pine, Gilmore, 1999). There are suspecting that the development of fitness clubs will be located in the broader context of social life.

\section{Impact of selected conditions on the functioning and development of the fitness market in Poland}

There are some factors that influencing on fitness market in the world and in Poland, both on supply and demand side. As a result of the analysis of many sources, the authors identified key determinants in the fields of PEST and showed their impact on fitness market in Poland.

Table 3. Key determinants of the development of the fitness market in Poland

\begin{tabular}{ll}
\hline \multicolumn{1}{c}{ The determinants } & \multicolumn{1}{c}{ Impact on fitness market in Poland } \\
\hline \multicolumn{1}{c}{ Political and legal determinants } \\
\hline $\begin{array}{l}\text { Law regulating the performance } \\
\text { of certain professions }\end{array}$ & $\begin{array}{l}\text { This may limit or eliminate requirements for the performance of certain professions, including those related to } \\
\text { the fitness of club fitness clients. It may increase competition in the market, more creativity in the preparation } \\
\text { of service packages, the involvement of those who have not been professionally involved in consulting. } \\
\text { Club fitness managers should observe documents related to, for example, recommendations related to the } \\
\text { physical activity of the population, sports, the role of sport in the life of the European Union citizens }\end{array}$ \\
$\begin{array}{l}\text { Resolutions of municipal councils, } \\
\text { city councils (e.g. budget for sports } \\
\text { activities) }\end{array}$ & $\begin{array}{l}\text { They are important, for example, in the case of product preparation - events, extracurricular activities, where } \\
\text { cooperation with public institutions operating in the municipality may be undertaken. Cities in Poland attach } \\
\text { great importance to sport, but expenditures on the promotion of physical activity of residents are varied. } \\
\text { Physical activity programs for older people or subsidies for large families may appear. }\end{array}$ \\
\hline Interest rates on investment loans & $\begin{array}{l}\text { Economic and financial determinants } \\
\text { Managers must observe different economic indicators and, in the case of high financial burdens and } \\
\text { unfavorable alternatives, may lead to less flexibility in the price of a club fitness product and less inclination } \\
\text { to search for new products for clients. } \\
\text { A large number of customers in the afternoons will cause the club's fitness manager to try to raise prices for } \\
\text { services during this period. }\end{array}$ \\
\hline
\end{tabular}

${ }^{5}$ E.g. Calypso, Jatomi Fitness, Fabryka formy, Fitness Platinum, S4 Fitness Club, Energy fitness, Fitness Academy, Zdrofit, Fitness World, Mrs Sporty

${ }^{6}$ This is confirmed by the diversified structure of capital, the wide overview of the fitness market in Poland in the world, the high motivation for further development caused by shareholders' expectations.

${ }^{7}$ Political-legal, economic, socio-cultural and technological. 


\begin{tabular}{|c|c|}
\hline 1 & 2 \\
\hline Economic development of the regions & $\begin{array}{l}\text { This is a strong factor strengthening the process of improving the quality of the offer and expanding it with new } \\
\text { additional services for companies and increasingly prosperous customers. }\end{array}$ \\
\hline Business assistance programs & $\begin{array}{l}\text { It is important to observe EU programs as well as local initiatives, as they can significantly support material } \\
\text { investment as well as staff training or promotional activities of a club fitness product (e.g. trips to foreign fairs). }\end{array}$ \\
\hline \multicolumn{2}{|r|}{ Socio-cultural determinants } \\
\hline Demographic change & $\begin{array}{l}\text { More and more women and older people participate in fitness clubs. The offer for them is constantly widened, } \\
\text { for example, in the organization of new classes and new partners for loyalty programs. }\end{array}$ \\
\hline Active lifestyle & $\begin{array}{l}\text { The popularity of sports activities promotes the enrichment and expansion of the offer for the residents as } \\
\text { well as the offer for hotel guests and other visitors for recreation and active leisure time in the fitness clubs. }\end{array}$ \\
\hline $\begin{array}{l}\text { Increasing willingness to participate } \\
\text { in events }\end{array}$ & $\begin{array}{l}\text { Modern equipped exercise rooms, with multimedia equipment, are more and more important to clients. And } \\
\text { offer of modern fitness clubs is combined with admission to other sporting events. }\end{array}$ \\
\hline \multicolumn{2}{|r|}{ Technological and technological determinants } \\
\hline Development of public infrastructure & $\begin{array}{l}\text { With the development of public transport - the availability of public transport allows managers to raise prices } \\
\text { for certain services in fitness clubs located in city centers, near business facilities, hotels }\end{array}$ \\
\hline Automation & $\begin{array}{l}\text { The security or the organization of the space around the club's fitness area (parking area) is supported by } \\
\text { modern automatic technology, which raises operational costs but also makes it possible to distinguish itself } \\
\text { in a competitive market. }\end{array}$ \\
\hline Internet and mobile technologies & $\begin{array}{l}\text { The tendency and ability of customers to use the Internet contact form is growing. This necessitates more } \\
\text { care for fitness managers in the form of Internet communication as well as organization of the customer } \\
\text { service process using the Internet or mobile applications. }\end{array}$ \\
\hline
\end{tabular}

"Ustawa z dnia 13 czerwca 2013 r. o zmianie ustaw regulujących wykonywanie niektórych zawodów.

Source: own elaboration.

There is significant impact of the determinants described in table 3 on developing fitness market in Poland. The described phenomena already occur, however, with varying degrees of intensity in different parts of the countries, regions, cities (Cieślikowski, Brusokas, 2017). It seems that dynamics of change is especially high in capital of province as well as in those regions where significant public investments have been made in the development of sports infrastructure, including multifunctional sports facilities. There were built huge venues with inside halls, rooms for new fitness clubs too.

\section{Conclusions}

The fitness market in Poland will continue to grow. This is due to many factors, political, legal, economic, financial, social as well as technical and technological. The determinants depend on megatrends in the world (Megatrends, 2015) and depend on the economic and social changes of many areas of life in Poland.

The fitness services market will become more professional and better organized. On the market can be identified in the nearest future many new technologies related with internet technologies and new fitness tools (i.e. real things). There will be more and more companies operated on the institutional clients service process. The companies have so far carried out an institutional client in other markets. However, they will now also be trying to offer fitness services (e.g. Medicover, Luxmed, Polmed). And employers for employee retention will be extending social care including the offer of fitness services with increasingly interesting programs. Developing polish economy caused the capital surplus of some companies is still increase, and to have benefits from tax related with investments will be support the growing number of new fitness clubs in Poland. There will also be a faster development of fitness clubs chains due to increased sales activity of franchise solution providers. Such trends on the supply side of fitness market will be together to the development of demand side caused by the 
increasing healthy living and well organized (under control of professionals and well-prepared equipment, in the rooms dedicated for this purpose) physical activity.

\section{References}

Cieślikowski, K., Brusokas, A. (2017). Determinants of effective management in the sport with the use of large sport arenas in selected cities. European Journal of Service Management, 1 (21), 5-10.

European Health \& Fitness Market Report (2017). Warszawa: Delloite.

Fonfara, K. (2014). Marketing partnerski na rynku przedsiębiorstw. Warszawa: Polskie Wydawnictwo Ekonomiczne.

Gardawski, J., Gilejko, L., Siewierski, J., Towalski, R. (2008). Socjologia gospodarki. Warszawa: Wydawnictwo Diffin.

Kantyka, J., Maciąg, J. (2013). Aktywność innowacyjna mikro i małych przedsiębiorstw sportowo-rekreacyjnych na przykładzie fitness klubów - wyniki badań. Handel Wewnętrzny, 2,9 (10), 136-148.

Kotler, P. (1994). Marketing. Analiza, planowanie, wdrażanie i kontrola. Warszawa: Wydawnictwo Gebethner i S-ka.

Megatrends 2015. Making sense of a world in motion (2015). EYGM Limited. Retrieved from: http://www.ey.com (18.06.2017).

Niestrój, R. (2002). Zarządzanie marketingiem. Aspekty strategiczne. Warszawa: Wydawnictwo Naukowe PWN.

Panfil, R. (2016). Usługi rekreacyjne - kreowanie i udostępnianie. Wrocław: Akademia Wychowania Fizycznego.

Pestka, P. (2015). Zarządzanie czasem wolnym a zachowania polskich konsumentów na rynku fitness - case study. Research Journal the Wroclaw School of Banking, 6 (15), 846-852.

Pine, B.J., Gilmore, J.H. (1999). The Experience Economy: Work Is Theater \& Every Business a Stage. Harvard Business School Press. Raport z badań (2013). Aktywność sportowa Polaków. Warszawa: CBOS.

Raport (2015). Sportowa dekada. MultiSport zmienia przyzwyczajenia Polaków. Rynek świadczeń pozapłacowych oraz branżę fitness. Warszawa: Benefit Systems SA.

Sznajder, A. (2015). Marketing sportowy. Warszawa: Polskie Wydawnictwo Ekonomiczne.

Ustawa z dnia 13 czerwca 2013 r. o zmianie ustaw regulujących wykonywanie niektórych zawodów. Retrieved from: www.infor.pl (5.05.2017).

Wrzosek, W. (2002). Funkcjonowanie rynku. Warszawa: PWE.

Cite this article aS: Cieślikowski, K., Kantyka, J. (2018). Fitness market in Poland and its determinants. European Journal of Service Management, 2 (26), 37-44. DOI: 10.18276/ejsm.2018.26-05. 